\title{
THE ROYAL SWEDISH ACADEMY OF SCIENCE
}

\section{Bicentenary Celebrations}

\author{
By DR. J. Ramsbottom, O.B.E., President of the Linnean Society
}

$\mathrm{T}^{\mathrm{H}}$ HF inaugural meeting of the Royal Swedish Academy of Science (Kungl. Srenska Vetenskapsakademien) took place on June 2, 1739, and the celebration of its bicentenary is to be held in Stockholm during September 23-25.

The Academy was founded mainly on the suggestion of Captain Marten Triewald, who enlisted as supporters for a scientific academy publishing in Swedish, Jonas Alström, Baron Sten Carl Bjelke, Carl Wilhelm Cederhielm, Baron Anders Johan von Höpken and Carl Linnæus. A meeting. was called at the Riddarhuset (House of Nobles) to form an "Economic Scientific Academy for the promotion of useful sciences"; the name
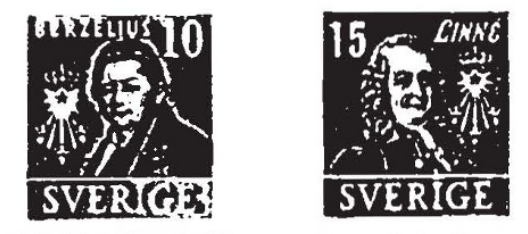

Two of the Stamps isSUed bi the Sweidsh Post Office to Mark tir BICFNTENARY CELEBRATIONS OF THF. Roval Swedish Acadf.MY.

"Swedish Academy of Science" was adopted, however, on the advice of Anders Celsius. The first president, chosen by lot, was Linnaus, then thirtytwo years of age; the first secretary was von Höpken, an influential young nobleman who later filled in turn the highest offices of State. Von Höpken was responsible for drawing up the proposed statutes adopted at the inaugural meeting, and confirmed later by the King, who permitted "Royal" to be added to the title of the Academy. Linnæus was president only for the first four months and each of the original members succeeded him, sooner or later, in office. Under his presidency, thirty new members were elected, many of them men whose support he valued.

Subscriptions at first were in cash and in kind, Linnæus's presentation of a copy of his "Hortus Cliffortianus" and two Chinese books, on rice and silkworms, starting the present rich library. The printing of the Transactions was planned, with a device for the title-page of an old man planting a palm tree, and the inscription "För Efterkom- mande"; an original sketch for this is in the possession of the Linnean Society of London. On relinquishing office, Linnæus delivered a formal oration, "On Curiosities in Insects", setting an example followed by all succeeding presidents.

In 1747, the Academy was granted the privilege of publishing the Almanack and Statc Calendar, a privilege several times renewed, and which is still its chicf source of income.

The Academy was immediately successful, and by 1746 its membership had reached one hundred, a number to which the Swedish membership was later formally limited and it was only this year that it was agreed that in certain circumstances the number may be increased to one hundred and thirty. The prestige of the Academy led to the election of many of the most prominent men in the country, but though it was realized that much was to be gained socially and financially by this it was insisted upon that there should be real and active participation by all those elected. The earliest statutes expressly ruled that if any member "contrary to expectation" had not for two years sent in any work or done anything to promote the welfure of the Academy, such a member "being superfluous" should, after two years, lose his seat and his vote in the deliberations. Obviously such a rule was tricky to apply, and motions to effect it were occasionally shelved. However, five members were expelled in 1748, and 1783 saw the last of such expulsions.

Early in its history, the Academy undertook. the building of an astronomical observatory for which the city of Stockholm contributed the site and the State made a grant; the establishment was removed to a new observatory at Saltsjöbaden, ten miles south-east of Stockholm, in 1931. Pehr Wilhelm Wargentin, the famous astronomer and statistician, became director of the Observatory on its completion in 1753; he had served as secretary of the Academy since 1749 , and with an enormous capacity for work he was able to continue in office until his death in 1783, having an assistant, provided from a private source, only in the last seven years.

After Wargentin's death, the Academy suffercd a period of decline doubtless connected with the difficulty of finding an efficient and energetic successor. Yarions expedients were tried in order to lighten the labours of the principal secretary, 
but it was not until the celebrated chemist Jöns Jakob Berzelius took on the post in 1818 that satisfactory progress was resumed.

Elections were made in the cighteenth century without regard to a properly balanced representation of the different branches of learning. Different proposals were put forward to alter this, and in 1798 it was agreed to divide the members into seven groups. The stated object of the Academy was the promotion of useful sciences, and the first two groups, National Economy and Agriculture and Trade and Commerce accounted for a quarter of the members. Berzelius with his organizing ability and broad views soon brought about changes. In 1821 he had the two 'practical' groups combined and the Natural Science and Medicine groups increased from four to seven with the object of making the Academy purely scientific. 'I'his classification lasted until 1904, when a revision was necessary owing to the task of awarding two of the Nobel prizes-the aim being to give more prominence to chemistry and physics. He also had the rules for electing members revised. Fach group had to submit " $\mathrm{n}$ well-thought-out and wellfounded proposal" which was placed before a full meeting of the Academy. Berzelius was insistent that it was the duty of members to keep in touch with the progress of research, and the annual festival of the Academy (March 31) was chosen for the delivery' of reports on the different branches of science. The reports during Berzelius's long tenure of office were augmented and published, he himself being responsible for chemistry, and for physics also until 1839. The series was translated into French and German and was of the greatest importance; but the task of preparation grew heavier, and shortly after Berzelius's death in 1848 it was found impossible to continue them. Not only did Berzelius lay the foundation of the present constitution of the Academy, but also by obtaining a fixed annual grant for the library and greatly extending its exchanges insured its present eminence.

Like all such national socicties, the Academy became possessed of large museum collections, which gradually became too extensive for the curatorial facilities it could afford. When therefore Gustav von Paykull presented his large zoological collections to the Crown in 1819, and the King entrusted their care to the Academy, the Academy presented its orn zoological collections to the State. Thus began the Naturhistoriska Riksmuseum which, though a national museum, is under the supervision of the Academy. In 1841 the botanical, mineralogical and ethnographical collections were also transferred to the IIuseum. Recently the last-named have been separated off as an independent institution-
Statens etnografiska museum-which, however, is still supervised by the Acadcmy.

A bequest by P. J. Bergius in 1790 of his estate of Bergiclund just outside Stockholm for the purpose of establishing there a model botanical garden scarcely achieved its object because of lack of funds for ninety years or so. Then owing to the growth of Stockholm the area was included within the city boundaries with a consequent increase in value; the eighteen acres were sold and a site of more than sixty acres purchased about a mile north of the city and the present Bergian Garden established together with a School of Gardening. The president of the Academy for 1939-40, Prof. Robert E. Fries, is director of the Botanic Garden.

Among other institutions administered by the Academy are the Nobel Institute for Physical Chemistry set up in 1905 with S. A. Arrhenius as director until his death in 1927 ; this was replaced in 1933 by the Nobel Institute for Theoretical Physics with C. W. Oseen as director : the Kristineberg Marine Zoological Station, the Mittag-Leffler Foundation for Mathematics, the Physical Institute, the Abisko Natural Science Station and the Committee for the Protection of Nature.

The Academy usually meets twice monthly, except in summer, at Novra Djurgairden, a district which is commonly known as Vetenskapsstaden (Science City) and which may be compared in some ways with South Kensington. The annual festival is traditionally held in the Riddarhuset, and is usually attended by members of the Royal Family.

To mark the celebrations, the Swedish Post Office has issued four special stamps, two with a portrait of Linneus and two with that of Berzeliusone of each is illustrated here. The portrait of Linneus is apparently taken from the Academy's painting by Roslin and that of Berzelius from the one by Södermark.

The preliminary programme announces that the delegates and guests will meet on Saturday afternoon, September 23, at the Academy building and afterwards visit the institutions at Vetenskapsstaden. In the evening there will be an informal dinner. On Sunday afternoon, the bicentenary festival will be held in the Stockholm Concert IIall in the presence of H.M. the King and other members of the Royal Family. In the evening there will be a banquet in the Stockholm Town Hall. On Monday the Stockholm Observatory at Saltsjöbaden will be visited, tea will be taken at the Royal Palace and in the evening there will be a gala performance at the Royal Opera House.

Delegates have been sent a pamphlet on the history of the Academy prepared by Dr. Arne Holmberg, the Academy's. librarian. I have had free use of this in compiling the above account. 